\title{
$\Psi_{\text {IIEP }}$ International Journal of Educational Psychology
}

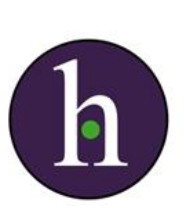

Instructions for authors, subscriptions and further details:

http://ijep.hipatiapress.com

\section{Psychological Impact of Work-Integrated Learning Programmes in Malaysia: The Moderating Role of Self-Esteem on Relation between Self-Efficacy and Self-Confidence}

Amar Hisham Jaaffar ${ }^{1}$, Hazril Izwar Ibrahim², Jegatheesan Rajadurai $^{1}$, M. Sadiq Sohail ${ }^{3}$

1) Universiti Tenaga Nasional

2) Universiti Sains Malaysia

3) King Fahd University of Petroleum and Minerals

Date of publication: June $24^{\text {th }}, 2019$

Edition period: June 2019 - October 2019

To cite this article: Jaaffar, A. H., Ibrahim, H. I., Rajadurai, J., \& Sadiq Sohail, M. (2019). Psychological Impact of Work-Integrated Learning Programmes in Malaysia: The Moderating Role of Self-Esteem on Relation between Self-Efficacy and Self-Confidence. International Journal of Educational Psychology, 8(2), 188-213. doi: 10.17583/ijep.2019.3389

To link this article: http://dx.doi.org/10.17583/ijep.2019.3389

\section{PLEASE SCROLL DOWN FOR ARTICLE}

The terms and conditions of use are related to the Open Journal System and to Creative Commons Attribution License (CC-BY).

2019 Hipatia Press

ISSN: 2014-3591

DOI: $10.17583 /$ ijep.2019.3389
Hipatia Press

www.hipatiapress.com

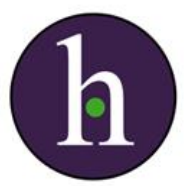




\section{Psychological Impact of Work- Integrated Learning Programmes in Malaysia: The Moderating Role of Self-Esteem on Relation between Self-Efficacy and Self-Confidence}

Amar Hisham Jaaffar

Universiti Tenaga Nasional

Jegatheesan Rajadurai

Universiti Tenaga Nasional
Hazril Izwar Ibrahim

Universiti Sains Malaysia

M. Sadiq Sohail

King Fahd University of

Petroleum and Minerals

\section{Abstract}

This study further extends a theoretical model of psychological empowerment by investigating the relationships between self-efficacy, self-confidence and selfesteem. A sample of by 383 of Malaysian undergraduates participating in Work Integrated Learning (WIL) programmes across five public universities is used to test the model employing partial-least squares based structural equation modelling. The results have demonstrated that self-efficacy and self-esteem have a positive and significant relationship with self-confidence. This study also confirms the moderating effect of self-esteem on the relationship between self-efficacy and selfconfidence. Furthermore, the findings of this study provide insight about psychological attributes of undergraduates participated in WIL programmes. These findings have implications for WIL stakeholders, which are highlighted in the paper.

Keywords: work-integrated learning; psychological attributes; psychological empowerment; higher education; Malaysia. 
IJEP - International Journal of Educational Psychology, Vol. 8 No. 2 June 2019 pp. 188-213

\section{Impacto Psicológico de Programas de Integración del Trabajo en Malasia: El Rol Moderador de la Autoestima en la Relación entre la Autoeficacia y la Autoconfianza}

Amar Hisham Jaaffar

Universiti Tenaga Nasional

Jegatheesan Rajadurai

Universiti Tenaga Nasional
Hazril Izwar Ibrahim

Universiti Sains Malaysia

M. Sadiq Sohail

King Fahd University of

Petroleum and Minerals

\section{Resumen}

Este estudio extiende un modelo teórico de empoderamiento psicológico por medio de investigar las relaciones entre la autoeficacia, la autoconfianza y la autoestima. Una muestra de 383 estudiantes de grado de Malasia participantes en Programas de Aprendizaje de Trabajo Integrado (WIL) en cinco universidades públicas se usa para examinar el modelo usando modelización de ecuaciones estructurales basadas en mínimos cuadrados parciales. Los resultados demuestran que la autoeficacia y la autoestima tienen una relación positive y significativa con la autoconfianza. Este estudio también confirma el papel moderador de la autoestima sobre la relación entre la autoeficacia y la autoconfianza. Además, los resultados arrojan luz sobre los atributos psicológicos de los estudiantes que participaron en estos programas. Los resultados tienen implicaciones para los usuarios de WIL, que se subrayan en el artículo.

Palabras clave: aprendizaje de trabajo integrado; atributos psicológicos; empoderamiento psicológico; educación superior; Malasia.

2019 Hipatia Press

ISSN: 2014-3591

DOI: 10.17583/ijep.2019.3389
Hipatia Press

www.hipatiapress.com




W ork-Integrated Learning (WIL) is a programme implemented by institutions of higher learning for undergraduates. WIL has widely been considered as being instrumental in providing new undergraduates with skills to find employability and function effectively in work place (Jackson, 2015). Educational theorists have suggested that WIL programmes are superior teaching tools compared to traditional learning tools (Ibrahim \& Jaafar, 2017). Despite the progressive development of WIL programmes, studies investigating the benefits of WIL have mainly focused on the economic as well as monetary benefits obtained by various stakeholders rather than the gains to specific undergraduates' learning outcomes or the on examining psychological attributes of the undergraduates (Drysdale et al., 2016; Potgieter, 2012). Recently, Jackson and Wilton (2016) called for WIL programmes to focus on undergraduates' psychological career resources or career meta-competencies.

In the context of WIL programmes, research is fragmented in investigating the relationship between psychological attributes including self-efficacy, self-esteem, and self-confidence of undergraduates after participating in WIL programmes. A previous study revealed that undergraduates who have participated in WIL programmes were found to have higher levels of perceived self-confidence, self-esteem, and selfefficacy compared to undergraduates who had not participated in WIL programmes (Drysdale et al., 2012). Another study undertaken in China, examined the mediating and moderating effects of global self-esteem on the relationship between social support and subjective well-being of undergraduate Chinese students (Kong et al., 2013). Review of literature reveals that no comprehensive study has examined the moderating effect of self-esteem on the psychological attributes of self-efficacy and selfconfidence of undergraduates participating in WIL programme. Thus, the aim of the current study is to fill this gap. This study proposes to investigate the relationship of an undergraduate's psychological attributes after participating in WIL programmes, which address self-efficacy, self-esteem, and self-confidence, as well as to examine the moderating effect of selfesteem. 


\section{Literature Review and Hypothesis Development}

The theoretical underpinning of this study is the concept of psychological empowerment in the context of WIL programmes. In general, psychological empowerment can be conceptualized as intrinsic motivation based on cognition including meaning, impact, self-determination, and competency (Spreitzer, 1995). Past research concludes that the form of psychological empowerment depends on the context and population being studied (Rappaport, 1984). WIL programmes provide an avenue for undergraduate psychological empowerment. A recent study has demonstrated this and concluded that intrinsic task motivation is manifested in a set of cognitions that include competence, impact, meaning, and self-determination, reflects an undergraduate's orientation to his or her work role (Drewery et al., 2016).

Psychological factors such as self-confidence, self-efficacy and selfesteem are important contributors to the psychological empowerment of the undergraduate students. This will lead to a higher rate of employability of these students. Previous studies revealed a positive and significant association between the employees' psychological empowerment and the attitudes and behaviours relating to their jobs (Islam et al., 2016). Another study also confirmed that psychological empowerment factors including meaning, impact, self-determination, and competency have a significant positive relationship with an organization's learning (Safari et al., 2011). However, these have been in organizational learning context. A recent study undertaken in Canada examines the perceptions of co-op students' towards work-term quality in order to predict their perceived work-term quality (Drewery et al., 2016). However, extant literature appears to have overlooked the potential comparative context of the undergraduate's psychological attributes in developing countries.

\section{Self-Confidence}

The concept of self-confidence has been widely discussed in psychology and applied research. Kukulu et al., (2013) define self-confidence as the ability of an individual to recognise his or her own ability, love towards himself/herself or an awareness of his or her own emotions. Carson et al., (2001) describe self-confidence as feelings of well-being because of deepening positive emotions. Self-confidence is reported as an integral psychological construct that affects a student's academic performance 
(Craven et al., 1991). Possessing self-confidence means there is an expectation that a person will achieve a goal in a certain situation. Kukulu et al. (2013) suggest the role of educational or teaching methods, such as WIL programmes, can influence the development of an undergraduate's selfconfidence.

Previous studies demonstrated that undergraduates who successfully participated in a comprehensive WIL programme have increased selfconfidence (Balta et al., 2012; Purdie et al., 2013; Spowart, 2011; Zegwaard \& McCurdy, 2014). Further, it has also been found that self-efficacy and self-esteem influence self-confidence (Dickerson \& Taylor, 2000). Yet, the relationship between the above-mentioned psychological attributes has received little attention.

\section{Self-Efficacy}

Bandura (1977) defined self-efficacy as an individual's conviction in his/her ability to regulate one's motivation, thought process, and environment to achieve certain outcomes. Since then, many studies have recognized self-efficacy as a motivational outcome. Carpenter (2011), suggested that having self-confidence in an individual's ability in completion of a difficult task will increase his/her likelihood of engaging such a behaviour in future. Likewise, lack of self-efficacy can reduce an individual's inclination to a behaviour or action when faced with challenging or complex circumstances (Hebert et al., 2014).

There is an increasing body of research that indicates that measures of academic self-efficacy are predictive of student academic achievement (Zajacova et al., 2005; Mazlum et al., 2015). High self-efficacy beliefs are also associated with the use of learning strategies (DiBenedetto \& Zimmerman, 2010). Moreover, self-efficacy is related to high academic performance and the use of self-regulatory strategies (Bembenutty, 2011). Self-efficacy also has been found to be an important predictor of an undergraduate's self-perceived employability and employment outcomes (Kanfer et al., 2001; Velde \& Berg, 2003).

Previous research has identified that WIL programmes enhance an undergraduate's level of self-efficacy (e.g. Bates et al. 2014; Edwards; 2014; Freudenberg et. al., 2011). Furthermore, other studies have also found that real life experiences gained through WIL programmes such as service 
learning programmes, increased the undergraduates' motivation to participate in research activities, as it elevates their perception of practice implications of their research (Harder, 2010; Deck et al.,2016). Raelin et al., (2011) examined the effect of WIL programmes such as cooperative education based on three dimensions of self-efficacy change and concluded WIL programmes significantly influence self-efficacy.

As for the relationship between self-efficacy and self-confidence, Dickerson and Taylor (2000) revealed that task specific self-efficacy influences an individual's self-confidence. This find support in other studies, which, demonstrated that self-efficacy has a positive relationship with the self-confidence (Raelin et al., 2011). This leads us to the Hypothesis 1: Selfefficacy of undergraduates who have participated in WIL programmes is positively related to self-confidence

\section{Self-Esteem}

Rosenberg (1965) defined self-esteem as an individual's positive or negative attitudes about themselves. High self-esteem would mean that an individual has a feeling of being good enough, while low self-esteem refers to a feeling of not being good enough. In order to have a high self-esteem, individuals attempt to have a control and mastery of their socio-cultural environment (Coetzee \& Bergh, 2009). Previous studies reveal that individuals having low self-esteem are more likely to perform poorly and achieve less than those with high self-esteem (Brockner \& Guare, 1983; Kerka, 1998). They are not confident that they will succeed in whatever task that they undertake (Baumeister, 1997).

Several studies have been conducted to examine the effect of self-esteem on students' self-confidence. Previous studies have concluded that students with low self-esteem could elevate themselves by participating in workbased learning (Brockner \& Guare, 1983; Fugate et al., 2004). Potgieter (2012) suggested that career meta-competencies such as self-esteem do influence undergraduate employability attributes significantly. Therefore, higher education institutions and employers should emphasize the importance of an undergraduate's self-esteem development in a WIL programme in order to improve his or her employability attributes.

Past studies have also examined the relationship between self-esteem and self -confidence and concluded with interesting relationships. Self-esteem 
and self-confidence were found to be interrelated concepts but mutually dependent (Feltz, 2007). This implies that certain people, who may not have high self-confidence in a given task, might value themselves highly. In contrast, some might consider themselves as highly competent at a given task but may not have similar feelings of self-esteem. In contrast, another study revealed that individuals with high levels of self-confidence have high levels of self-esteem (Kukulu et al., 2013). Further including the construct of self-efficacy, Dickerson \& Taylor (2000) demonstrated that self-esteem along with self-efficacy, are strong predictors of individual selfconfidence. They also suggested that there is a strong relationship between self-esteem and self-efficacy.

It should be noted that there is no unanimity as to the relationships between self-esteem and self-confidence in extant studies. Therefore, in addition to examining the direct relationship between self-esteem and selfconfidence, the present study also proposes that self-esteem will moderate the relationship between self-efficacy and self-confidence. The reasoning for such a proposition is grounded by closely examining relevant extant literature. Past studies have reported a moderating effect of the self-esteem construct on psychological variables and the psychological stress or wellbeing of university undergraduates (Kong et al., 2013; Moradi \& Subich, 2004). Another study concluded that self-esteem is an important psychological resource, which acts as a buffer against a stressful environment (Cast \& Burke, 2002). A study undertaken in Turkey revealed that there was a significant positive relationship between self-esteem and academic achievement of Turkish undergraduates (Duru \& Balkis, 2017). Kong et al. (2013) examined the moderation effect of self-esteem between social support and life satisfaction. As such, the logical sequence suggests that self-esteem may have an influence on the on the relationship between self-efficacy and self-confidence. Therefore, are proposed Hypothesis 2: Self-esteem of undergraduates who had participated in WIL programmes is positively related to self-confidence, and Hypothesis 3: The relationship between self-efficacy and self-confidence of undergraduates who had participated in WIL programmes becomes stronger when the level of selfesteem is high". 


\section{Method}

This study employs a purposive sampling technique as it targets a specific group of respondents, which is undergraduate participants in WIL programmes. This study focuses on the psychological attributes of the sample.

\section{Empirical Research Setting}

An assortment of WIL programmes have been used by educators in more than thirty countries all over the world (Nagy \& Smith, 2016). However, research on the use of WIL programmes in Malaysia is scanty. A recent study undertaken in Malaysia examines employers perception of undergraduates competence after their WIL programme, but this is confined to their employability skills (Jaaffar et al., 2016). This study is timely as the government of Malaysia has acknowledged the importance of providing a high-quality workforce which is responsive to local, as well as global forces, particularly since trading among nations of the world has become increasingly liberalised (Daud et al., 2011). Rigorous research on WIL programmes will help to have a better understanding of the effect of selfesteem on the psychological attributes of self-efficacy and self-confidence of undergraduates participating in WIL programmes. Thus, it is worthwhile exploring if there are such differences between the behaviour of undergraduate students in different countries such as Malaysia.

\section{Survey Instrument}

A structured questionnaire was developed based on a thorough review of literature. Multi-item measurement scales were used to operationalise the dependant and independent variables. The self-confidence construct consists of seven items adopted from Shrauger's (1995) Personal Evaluation Inventory (PEI) scale. The self-efficacy construct consists of eight items adopted from Chen's et al. (2001) General Self-efficacy Scale and Freudenberg, et al., (2010). The self-esteem construct consists of five items adopted from Rosenberg's (1965) Self-Esteem Inventory scale (Garcia et al., 2019). All these items are detailed in Table 1. All items were measured on a the five-point Likert scale with 1 representing "strongly disagree" and 5 representing "strongly agree". The questionnaire in English was used aimed 
to capture the perception of the undergraduate respondent's psychological attributes after completing WIL programmes. A section to capture the demographic profile of the respondents was also included.

\section{Data Collection}

The study utilized a cross-sectional approach. Respondents were undergraduates studying for business management degrees at five Malaysian public universities and who had undergone various WIL programmes, including: 1) internship/placement/practicum, 2) industrial attachment, 3) research assistantships (paid/unpaid), 4) teaching assistantships, 5) job shadowing, 6) volunteering (community service) and 7) study abroad. Data was obtained through a purposive sampling method using a drop and collect approach. The surveys were only distributed to the undergraduates who had undergone WIL programmes with the cooperation of each business faculty's internship coordinator. This study used drop-off/pick-up survey technique where 500 questionnaires were distributed to internship coordinators of five Malaysian Public universities (Jackson-Smith et al., 2016) . The survey was conducted at one point in time over a period of two months. Overall 389 responses were received, of these six responses were dropped from further analyses, as they were not fully completed. This left us with 383 usable responses indicating 76.7 percent response rate.

\section{Descriptive Statistics}

The descriptive statistic in Table 1 shows that, 89 respondents were male (23.2 percent) and 294 were female (76.8 percent). Three hundred seventy $(96.6 \%)$ of respondents had undergone an internship/placement/practicum, $26(6.8 \%)$ industry attachment, $8(2.1 \%)$ had undergone research assistantships (paid/unpaid), 12 (3.15) had undergone teaching assistantships, 4 (1\%) had undergone job shadowing, 61 (15.9\%) had undergone volunteering (community service) and $7(1.8 \%)$ had undergone 'study abroad'. The result also indicated that 105 (27.4\%) of respondents have WIL experience in more than one programme. The percentage of male and female students in this study reflects the current scenario in public universities in Malaysia, where, generally speaking, the percentage for female students is higher than male students consistent with statistics released by the Ministry of Higher Education (2013). The choice of WIL 
activities used in this study is consistent with the definition of WIL proposed by Martin et al. (2012).

Table 1

Descriptive Statistics

\begin{tabular}{lll}
\hline Description & Frequency $(\mathrm{N}=383)$ & Percentage \\
\hline Gender & & \\
Male & 89 & 23.2 \\
Female & 294 & 76.8 \\
Training Programmes Involved & & \\
Internship/Placement/Practicum & 370 & 96.6 \\
Industry Attachment & 26 & 6.8 \\
Research Assistantship (paid/unpaid) & 8 & 2.1 \\
Teaching Assistantship & 12 & 3.1 \\
Job Shadowing & 4 & 1.0 \\
Volunteering (community service) & 61 & 15.9 \\
Study abroad & 7 & 1.8 \\
\hline
\end{tabular}

\section{Data Analysis Technique}

The research hypotheses were tested using the Partial Least Square (PLS) method and used the software application SmartPLS software (Ringle et al., 2005). This study used PLS because of its flexible restriction with regard to the in respect to the distribution and population of the study. PLS also has potential to provide a more reliable and accurate computation of moderating effects since its takes into account errors which has the capability to reduce the possible relationship and thereby improve theory validation (Henseler \& Fassott, 2010). Following procedures suggested by Anderson \& Gerbing (1988), a two-stage analytical procedure was employed. This included a) testing the validity and reliability of the measurement model and b) testing the hypothesized relationship of the structural model. Finally, a bootstrapping method (5000 re-samples) was performed to test the significance of the path coefficients and the loading of the variables (Hair et al., 2014). 


\section{Results}

\section{Measurement model results}

To confirm the reliability of items, a confirmatory factor analysis (CFA) was first undertaken. The convergent validity and discriminant validity were also established. Three items from the construct of self-efficacy and two items from self-esteem were deleted as the loadings did not meet the critical threshold limit of 0.50 (Anderson \& Gerbing, 1988; Bagozzi and Yi, 1988). The internal consistency reliability was also achieved using composite reliability as the values were more than the required cut-off value of 0.70 (Chin, 1998; Hair et al., 2012) (Table 2). The average variance extracted (AVE) met the minimum criteria of 0.5 , confirming convergent validity (Fornell \& Larcker, 1981). The scale items, loadings, composite reliability and AVE are provided in Table 2.

Table 2

Scales, loadings, composite reliability and average variance extracted

\begin{tabular}{|c|c|c|c|c|}
\hline Constructs & Label & Loadings & C. $\mathrm{R}$ & AVE \\
\hline \multicolumn{5}{|l|}{ Self-Confidence } \\
\hline I have control over my own life & CON1 & 0.7490 & \multirow[t]{7}{*}{0.867} & \multirow[t]{7}{*}{0.567} \\
\hline I am easy to like. & CON2 & 0.7385 & & \\
\hline I never feel down for very long. & CON3 & 0.6860 & & \\
\hline $\begin{array}{l}\text { I am not embarrassed to let people know my } \\
\text { opinions. }\end{array}$ & CON4 & 0.8091 & & \\
\hline $\begin{array}{l}\text { If a task is difficult, that makes me even more } \\
\text { determined. }\end{array}$ & CON5 & 0.7763 & & \\
\hline I feel emotionally mature. & CON6 & DEL & & \\
\hline I like myself even when others do not. & CON7 & DEL & & \\
\hline \multicolumn{5}{|l|}{ Self-Efficacy } \\
\hline $\begin{array}{l}\text { My belief that I will achieve most of the } \\
\text { career goals that I have been able to set for } \\
\text { myself. }\end{array}$ & EFF1 & DEL & \multirow[t]{3}{*}{0.880} & \multirow[t]{3}{*}{0.514} \\
\hline $\begin{array}{l}\text { My certainty that I will accomplish difficult } \\
\text { tasks when faced with them. }\end{array}$ & EFF2 & 0.7270 & & \\
\hline $\begin{array}{l}\text { My general belief that I can obtain outcomes } \\
\text { that are important to me }\end{array}$ & EFF3 & 0.5733 & & \\
\hline
\end{tabular}




\begin{tabular}{|c|c|c|c|c|}
\hline $\begin{array}{l}\text { My belief that I can succeed at almost any } \\
\text { endeavour to which I set my mind. }\end{array}$ & EFF4 & 0.6119 & & \\
\hline $\begin{array}{l}\text { My ability to overcome successfully many } \\
\text { challenges. }\end{array}$ & EFF5 & 0.7622 & & \\
\hline $\begin{array}{l}\text { My confidence that I can perform effectively } \\
\text { on many different tasks. }\end{array}$ & EFF6 & 0.7846 & & \\
\hline $\begin{array}{l}\text { My ability to do most tasks very well } \\
\text { compared to other people. }\end{array}$ & EFF7 & 0.7721 & & \\
\hline $\begin{array}{l}\text { My ability to perform quite well even when } \\
\text { things are tough. }\end{array}$ & EFF8 & 0.7577 & & \\
\hline \multicolumn{5}{|l|}{ Self-Esteem } \\
\hline I am happy with who I am. & EST1 & DEL & 0.775 & 0.535 \\
\hline I am sure I will be able to reach my goals. & EST2 & DEL & & \\
\hline I have many things to be proud of. & EST3 & 0.7106 & & \\
\hline I feel that I am a success. & EST4 & 0.7016 & & \\
\hline $\begin{array}{l}\text { If I meet a copy of myself, I would enjoy } \\
\text { talking to this person. }\end{array}$ & EST5 & 0.7789 & & \\
\hline
\end{tabular}

The discriminant validity, as shown in Table 3, is also established because the square root of the AVE was higher than the inter-correlation of each of the study's constructs in relation to other constructs of the research model and also higher than the construct correlation (Chin, 2010). Therefore, it is safely assumed that the measurement model in this study meets the internal consistency reliability, convergent and discriminant validity.

Table 3

Discriminant validity

\begin{tabular}{llll}
\hline Variables & Self-Confidence & Self-Efficacy & Self-Esteem \\
\hline Self-Confidence & 0.7530 & & \\
Self-Efficacy & 0.4100 & 0.7169 & \\
Self-Esteem & 0.4871 & 0.3591 & 0.7314 \\
\hline
\end{tabular}




\section{Structural Model Results (PLS Path with moderator)}

To assess the results of structural model using PLS-SEM, the procedure outlined by Hair, Hult, Ringle, and Sarstedt (2013) were employed. These procedures call for assessing the four key criteria in the structural model. These include assessments of: a) the significance of the path coefficients, b) the coefficient determination $\left(R^{2}\right)$, c) the size effect $\left(f^{2}\right)$, and finally d) the predictive relevance $\left(Q^{2}\right)$. Following these procedures, results for the assessment of the significance of path coefficients are presented in Figure 1, and Table 4. The structural model in Fig. 1 presents a path model with two direct effects (EFF->CON) and EST-> CON), and one indirect (moderating) effect $\left(\mathrm{EFF}^{*} \mathrm{EST}->\mathrm{CON}\right)$.

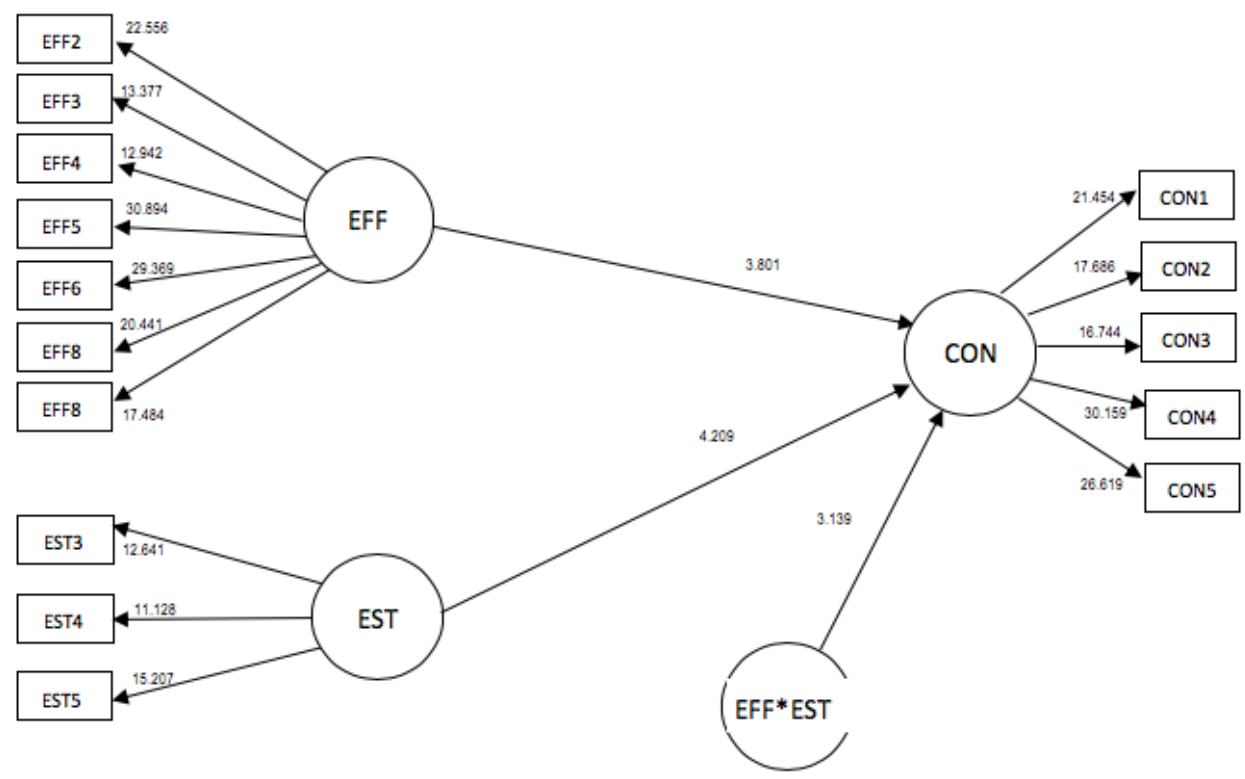

Figure 1. Structural model 
This study examined the moderating role of self-esteem on the relationship between self-efficacy and self-confidence. Table 4 presents the summary results of findings. The results indicated there is a positive relationship between self-efficacy with self-confidence $(\beta=1.4556 ; t=3.8013 ; p=0.00)$ The results also revealed that a positive relationship exists between selfesteem and self-confidence $(\beta=1.4331 ; 4.2095 ; p=0.00)$. The moderation result showed self-esteem moderates the relationship between self-efficacy and self-confidence $(\beta=-1.8464 ; t=3.1389 ; p=0.00)$, with the negative and significant relationships.

Table 4

Path coefficients for hypotheses testing

\begin{tabular}{llllll}
\hline Hypothesis & Beta & $\begin{array}{l}\text { Standard } \\
\text { Error }\end{array}$ & $\begin{array}{l}\text { T- } \\
\text { Statistic }\end{array}$ & $\begin{array}{l}\text { P- } \\
\text { Value }\end{array}$ & Decision \\
\hline EFF-> CON & 1.4556 & 0.3829 & 3.8013 & $0.00 * *$ & $\begin{array}{l}\text { ACCEPTE } \\
\text { D } \\
\text { ACCEPTE }\end{array}$ \\
EST-> CON & 1.4331 & 0.3405 & 4.2095 & $0.00 * *$ & D \\
EFF*EST $\rightarrow>$ & - & & & & \\
CON & 1.8464 & 0.5882 & 3.1389 & $0.00 * *$ & REJECTED \\
\hline
\end{tabular}

$* * \mathrm{p}<0.01$

Figure 2 demonstrates that the relationship will be weaker for undergraduates with higher self-esteem than undergraduates will with lower self-esteem. 


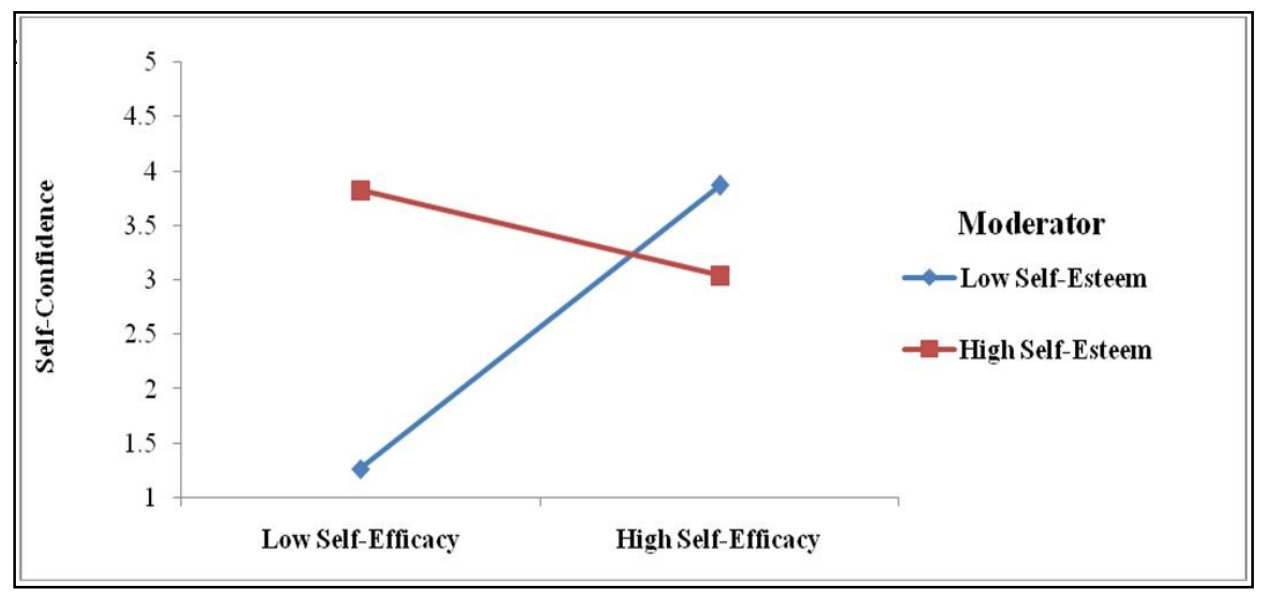

Figure 2. Interaction effects

The analysis also provided strong support to the structural model. The coefficient determination $\left(R^{2}\right)$ of the model is 0.329 implying that selfefficacy and self-esteem together explained 32.9 percent changes or variations in self-confidence among the undergraduates who have participated in WIL Programmes. Chin (1998) classified the R-squared of $0.19,0.33$ and 0.67 as weak, moderate and substantial respectively. The $R^{2}$ value can be considered as moderate. The effect-size $\left(f^{2}\right)$.is another criterion for assessing a structural model. Cohen (1988) classified effect-size of 0.02, 0.15 and 0.35 as small, medium, large respectively. The effect size $\left(f^{2}\right)$ of the self-efficacy is 0.13 can be classified as medium. While, the effect sizes $\left(f^{2}\right)$ of the self-esteem (moderator) is 0.21, which is higher than that of independent variables can also be classified as medium. The final evaluation criterion for the structural model is predictive relevance $\left(Q^{2}\right)$. This is evaluated by using the construct-cross validated redundancy. The model is said to have a predictive relevance, if $\left(Q^{2}\right)$ is greater than zero (Geisser, 1974; Stone, 1974). The $\left(Q^{2}\right)$ obtained in the present study is 0.1129 , or greater than zero. Predictive relevance of the model is also confirmed.

\section{Discussion}

This study was conducted based on the perception of undergraduates with regard to their psychological attributes including self-confidence, selfefficacy, and self-esteem after completing WIL programmes. The study 
examined the direct effect of self-efficacy and self-esteem on selfconfidence. It also examined the moderating role of self-esteem on the relationship between self-efficacy and self-confidence. The findings revealed that self-efficacy is positively related to self-confidence. This finding is consistent with previous findings. For example, Dickerson and Taylor (2000) revealed that task specific self-efficacy influences individual self-confidence. While, Raelin et al. (2011) demonstrated that self-efficacy has a positive and significant relationship with employees' self-confidence, this result shows that the self-efficacy of WIL undergraduates can be perceived as their belief in their own capabilities in a particular situation. Consequently, this will affect their self-confidence, manifested in the way in which they respond to their environment (Dacre-Pool \& Sewell, 2007).

This study also exhibited that self-esteem is positively related to selfconfidence. This finding is consistent with the study by Kukulu et al. (2013) which revealed that individuals with high levels of self-esteem have high levels of self-confidence. Moreover, Dickerson and Taylor (2000) demonstrated that self-esteem is one of the strongest predictors of individual self-confidence. In the context of post-WIL undergraduates who have satisfied their need for self-esteem, they will tend to feel confident, competent, strong and useful. This is in strong contrast to undergraduates whose self-esteem has not improved. This group tends to feel inferior, anxious, worried, depressed, weak and helpless (Coetzee and Bergh, 2009). Furthermore, WIL undergraduates with low self-esteem may be more inclined to perform poorly and underachieve compared to individuals with high self-esteem (Brockner \& Guare, 1983; Kerka, 1998).

This study also revealed that self-esteem moderates the relationship between self-efficacy and self-confidence in negative direction. The relationship between self-efficacy and self-confidence of undergraduates who had participated in WIL programmes becomes weaker when the level of self-esteem is high. Although previous studies identified the positive influence on the moderating effect of self-esteem, this study found otherwise. This may be due to certain factors such as whether undergraduates value themselves highly (high self-esteem) but do not have the self-confidence to complete a given task (low self-confidence). By contrast, there are undergraduates who may consider themselves as highly competent at a given task (high self-confidence) but do not have 
commensurate feelings of self-worth (low self-esteem) (Feltz, 2007). Furthermore the undergraduate's self-esteem may be influenced by 'high' and 'bad' self-esteem (Tracy, Cheng, Robins, \& Trzesniewski, 2009). In other words, 'high' self-esteem can be referred to as 'genuine' self-esteem (more socially desirable and achievement oriented) while, 'low' self-esteem can be referred to as 'fragile' self-esteem (more narcissistic and related to arrogance). 'High' self-esteem has been found positively related to supportive relationships, whereas 'low' self-esteem is associated with antisocial behaviour (Tracy et al., 2009). Beside those two factors, the gender of the respondents may influence the results as indicated by Kukulu et al. (2013), who found that male post-WIL undergraduates have higher self-esteem than female post-WIL undergraduates do.

From the perspective of psychological empowerment theory, the study of the relationship of WIL's psychological attributes, including self-efficacy, self-esteem, and self-confidence provide insight with regard to the undergraduates' post-WIL's cognition which is reflected in their orientation to their work roles in WIL programmes as well as on their future careers. For example, self-efficacy is related to competence, which indicates an undergraduate's belief in his/her capability to perform in a given role, while self-esteem is related to the degree to which they feel a sense of influence over the work that they perform. Their self-confidence is related to meaning, which demonstrates that undergraduates want experiences which are personally relevant to them and in which they find deep meaning. At the same time their self-determination refers to their seeking freedom to complete work in a way that they consider to be the most effective (Drewery et al. 2016). Moreover, this study demonstrates that WIL programmes act as psychological empowerment mechanisms, which are vital for an undergraduate's employment prospects. This is manifested through the positive relationship between an undergraduate's self-efficacy and selfconfidence developed because of participating in WIL programmes. The moderation effect of self-esteem also demonstrates the significant influences of these psychological attributes related to the undergraduates' psychological empowerment.

This study has practice implications. The study provides valuable insights of the WIL programme to stakeholders, specifically employers who act as hosts for undergraduate WIL programmes. This study also reinforces 
the contention that employers must be prepared to implement WIL programmes, because the undergraduates' experience of these programmes varies enormously in terms of their quality, educational value and psychological impact (Smith \& Worsfold, 2014).

The findings of this study lead to larger generalization. WIL programmes for undergraduates could be enhanced by having a structured approach (Smith et al., 2016). Administrators in higher education, as well as employers responsible for WIL programmes must aim to improve the undergraduates' self-efficacy, self-esteem and self-confidence for their psychological empowerment.

\section{Limitation and Suggestions for Future Research}

As in most empirical studies, this study is not without its limitations. First, rather than just focusing on Malaysian undergraduates from business management degrees, future studies should focus on undergraduates studying for engineering degrees in order to increase the generalizability of the study. Second, this study tested applied to psychological attributes, selfefficacy, self-esteem and self-confidence. However, other variables may have associations. For instance, the measurement of self-esteem comprises three components: general self-esteem, social or peer self-esteem and personal self-esteem. Future research may include alternative measurements of psychological attributes. Third, the sample is not reasonably distributed across gender. Future research can overcome this issue by minimizing the differences between the two genders and study the influence of undergraduate's gender on their psychological attributes. An increasing number of studies that have focused on influence of gender (Asakereh \& Yousofi, 2018). Finally, longitudinal study is suggested to examine the effect of the variables in the model over time. Cross sectional data makes inference tenuous. These studies would make worthwhile contribution to body of knowledge. 


\section{References}

Anderson, J. C., \& Gerbing, D. W. (1988). Structural equation modeling in practice: A review and recommended two-step approach. Psychological bulletin, 103(3), 411-423, doi: 10.1037/00332909.103.3.411

Asakereh, A., \& Yousofi, N. (2018). Reflective thinking, self-efficacy, selfesteem and academic achievement of Iranian EFL students. International Journal of Educational Psychology, 7(1), 68-89, doi: 10.17583/ijep.2018.2896

Bagozzi, R. P., \& Yi, Y. (1988). On the evaluation of structural equation models. Journal of the Academy of Marketing Science, 16(1), 74-94, doi: 10.1007/BF02723327

Balta, M. E., Coughlan, J.-L., \& Hobson, P. (2012). Motivations And Barriers In Undergraduate Students' Decisions To Enroll In Placement Courses In The UK. Journal of International Education Research, 8(4), 399.

Bandura, A. (1977). Self-efficacy: toward a unifying theory of behavioral change. Psychological review, 84(2), 191, doi: 10.1037/0033295X.84.2.191

Bates, L., Nguyen, H., Sawhney, J., \& O'Connor, E. L. (2014). The effect of work-integrated learning in highlighting the complexity of work: a pilot study of work self-efficacy. Paper presented at the Work Integrated Learning: Building capacity-Conference Proceedings of the 2014 ACEN National Conference.

Baumeister, R. F. (1997). Chapter 26 - Identity, self-concept, and selfesteem: The self lost and found. Handbook of Personality Psychology, Academic Press, 681-710, doi: 10.1016/B978012134645-4/50027-5.

Bembenutty, H. (2011). Meaningful and maladaptive homework practices: The role of self-efficacy and self-regulation. Journal of Advanced academics, 22(3), 448-473, doi: 10.1177/1932202X1102200304.

Brockner, J., \& Guare, J. (1983). Improving the performance of low selfesteem individuals: An attributional approach. Academy of Management Journal, 26(4), 642-656, doi: 10.5465/255912.

Carpenter, J. (2011). Evaluating social work education: A review of outcomes, measures, research designs and practicalities. Social 
IJEP - International Journal of Educational Psychology, 7(1) 207

Work Education, $\quad 30(02), \quad 122-140, \quad$ doi: 10.1080/02615479.2011.540375

Carson, J., Harman, K., Webb, S., Kimonis, E., \& Kuipers, E. (2001). Assessing and measuring self-esteem in mental health: a comparison of scales in current use. Mental Health and Learning Disabilities Care, 4, 336-339.

Cast, A. D., \& Burke, P. J. (2002). A theory of self-esteem. Social forces, 80(3), 1041-1068, doi: 10.1353/sof.2002.0003

Chen, G., Gully, S. M., \& Eden, D. (2001). Validation of a new general selfefficacy scale. Organizational research methods, 4(1), 62-83, doi: $10.1177 / 109442810141004$

Chin, W. W. (1998). The partial least squares approach to structural equation modeling. Modern methods for business research, 295(2), 295-336.

Chin, W. W. (2010). How to write up and report PLS analyses Handbook of partial least squares (pp. 655-690): Springer.

Coetzee, M., \& Bergh, Z. (2009). Psychological career resources and subjective work experiences of working adults: An exploratory study. Southern African Business Review, 13(2), 1-31.

Cohen, J. (1988). The concepts of power analysis. Statistical power analysis for the behavioral sciences, 1-17.

Craven, R. G., Marsh, H. W., \& Debus, R. L. (1991). Effects of internally focused feedback and attributional feedback on enhancement of academic self-concept. Journal of educational psychology, 83(1), 17, doi: 10.1037/0022-0663.83.1.17

Dacre-Pool, L., \& Sewell, P. (2007). The key to employability: developing a practical model of graduate employability. Education + Training, 49(4), 277-289, doi: 10.1108/00400910710754435.

Daud, S., Abidin, N., Mazuin Sapuan, N., \& Rajadurai, J. (2011). Enhancing university business curriculum using an importance-performance approach: A case study of the business management faculty of a university in Malaysia. International Journal of Educational Management, 25(6), 545-569, doi: 10.1108/09513541111159059

Deck, S. M., Platt, P. A., \& McCord, L. (2016). Engaged TeachingLearning: Outcome Evaluation for Social Work Students in a 
Graduate-Level Service Learning Research Course. Advances in Social Work, 16(2), 233-248, doi: 10.18060/18302

DiBenedetto, M., \& Zimmerman, B. (2010). Differences in self-regulatory processes among students studying science: A microanalytic investigation. The International Journal of Educational and Psychological Assessment, 5, 2-24.

Dickerson, A., \& Taylor, M. A. (2000). Self-Limiting Behavior in Women

Self-Esteem and Self-Efficacy as Predictors. Group \& Organization Management, 25(2), 191-210, doi: 10.1177/1059601100252006

Drewery. D ., Nevison.C., Judene, T.P., Cormier, L., Barclayne, S and Pennaforte (2016). Examining the influence of selected factors on perceived co-op work-term quality from a student perspective, AsiaPacific Journal of Cooperative Education, 17(3):265-277

Drysdale, M., McBeath, M. L., Johansson, K., Dressler, S., Zaitseva, E., Helyer, R., \& Helyer, R. (2016). Psychological attributes and workintegrated learning: An international study. Higher Education, Skills and Work-Based Learning, 6(1), doi: 10.1108/HESWBL-02-20150004

Drysdale, M., Ward, L. J., Johansson, K., Zaitseva, E., \& Sheri, D. (2012). Comparing the Attributes of Students in Cooperative Education or Work-Integrated Learning Programs in Four Countries.

Duru, E., \& Balkis, M. (2017). Procrastination, self-esteem, academic performance, and well-being: A moderated mediation model. International Journal of Educational Psychology, 6(2), 97, doi: 10.17583/ijep.2017.2584

Edwards, M. (2014). The impact of placements on students' self-efficacy. Higher Education, Skills and Work-based Learning, 4(3), 228-241, doi: 10.1108/HESWBL-05-2014-0015

Feltz, D. L. (2007). Self-confidence and sports performance. Studies, 33(41), 50-66.

Fornell, C., \& Larcker, D. F. (1981). Evaluating structural equation models with unobservable variables and measurement error. Journal of marketing research, 39-50, doi: 10.1177/002224378101800104

Freudenberg, B., Brimble, M., \& Vyvyan, V. (2010). The penny drops: Can work-integrated learning improve students' learning? E-Journal of Business Education \& Scholarship of Teaching. 4(1), 42-61 
Freudenberg, B., Brimble, M., \& Cameron, C. (2011). WIL and generic skill development: The development of business students' generic skills through work-integrated learning. Asia-Pacific Journal of Cooperative Education, 12(2), 79-93.

Fugate, M., Kinicki, A. J., \& Ashforth, B. E. (2004). Employability: A psycho-social construct, its dimensions, and applications. Journal of Vocational behavior, 65(1),

14-38, https://doi.org/10.1016/j.jvb.2003.10.005

García, J. A., y Olmos, F. C., Matheu, M. L., \& Carreño, T. P. (2019). Self esteem levels vs global scores on the Rosenberg self-esteem scale. Heliyon, 5(3), $1-17$ https://doi.org/10.1016/j.heliyon.2019.e01378

Geisser, S. (1974). A predictive approach to the random effect model. Biometrika, 61(1), 101-107, doi: 10.1093/biomet/61.1.101

Hair, J. J. F., Hult, G. T. M., Ringle, C., \& Sarstedt, M. (2013). A primer on partial least squares structural equation modeling (PLS-SEM): Sage Publications.

Hair, J. J. F., Hult, G. T. M., Ringle, C. M., \& Sarstedt, M. (2014). A Primer on Partial Least Squares Structural Equation Modelling. Thousand Oaks, CA: SAGE.

Hair, J. J. F., Sarstedt, M., Ringle, C. M., \& Mena, J. A. (2012). An assessment of the use of partial least squares structural equation modeling in marketing research. Journal of the Academy of Marketing Science, 40(3), 414-433, doi: 10.1007/s11747-011-02616

Harder, J. (2010). Overcoming MSW students' reluctance to engage in research. Journal of Teaching in Social Work, 30(2), 195-209, doi: 10.1080/08841231003705404

Hebert, C., Kulkin, H., \& Ahn, B. (2014). Facilitating research self-efficacy through teaching strategies linked to self-efficacy theory. American International Journal of Social Science, 3(1), 44-50.

Henseler, J., \& Fassott, G. (2010). Testing moderating effects in PLS path models: An illustration of available procedures Handbook of partial least squares (pp. 713-735): Springer.

Ibrahim, H., \& Jaafar, A. (2017). The Outcomes of Work-Integrated Learning Programmes: The Role of Self-Confidence as Mediator 
between Interpersonal and Self-Management Skills and Motivation to Learn. Pertanika Journal of Social Sciences \& Humanities, 25(2). Islam, T., Khan, M. M., Bukhari, F. H., Tuggle, F., \& Chauvel, D. (2016). The role of organizational learning culture and psychological empowerment in reducing turnover intention and enhancing citizenship behavior. The Learning Organization, 23(2/3), doi: 10.1108/TLO-10-2015-0057

Jaaffar, A. H., Ibrahim, H. I., Annuar, K., Shah, M., \& Zulkafli, A. H. (2016). Work-Integrated Learning and Graduate Employability Skills: The Employers' Perspective. The Social Sciences, 11(21), 5270-5274.

Jackson, D (2015). "Employability skill development in work-integrated learning: Barriers and best practice", Studies in Higher Education, Volume 40, No. 2, pp 350-367, doi: 10.1080/03075079.2013.842221

Jackson-Smith, D., Dolan, M., Holyoak, G., Flint, C. G., Trentelman, C. K., Thomas, B., \& Ma, G. (2016). Effectiveness of the drop-off/pick-up survey methodology in different neighborhood types. Journal of Rural Social Sciences, 31(3), 35.

Jackson, D., \& Wilton, N. (2016). Developing career management competencies among undergraduates and the role of work-integrated learning. Teaching in Higher Education, 1-21. doi: 10.1080/13562517.2015.1136281

Kanfer, R., Wanberg, C. R., \& Kantrowitz, T. M. (2001). Job search and employment: A personality-motivational analysis and meta-analytic review. Journal of applied psychology, 86(5), 837, doi: 10.1037/0021-9010.86.5.837

Kerka, S. (1998). Career Development and Gender, Race, and Class. ERIC Digest No. 199.

Kong, F., Zhao, J., \& You, X. (2013). Self-Esteem as Mediator and Moderator of the Relationship Between Social Support and Subjective Well-Being Among Chinese University Students. Social Indicators Research, 112, 151-161. doi:10.1007/s11205-012-0044-6

Kukulu, K., Korukcu, O., Ozdemir, Y., Bezci, A., \& Calik, C. (2013). Self-confidence, gender and academic achievement of undergraduate nursing students. Journal of psychiatric and mental 
IJEP - International Journal of Educational Psychology, 7(1) 211

health nursing, 20(4), 330-335, doi: 10.1111/j.13652850.2012.01924.x

Martin, A., Rees, M., Edwards, M., \& Paku, L. K. (2012). An organization overview of pedagogical practice in work-integrated education.

Mazlum, F. Cheraghi, F. Dasta, M. (2015). English Teachers' Self-Efficacy Beliefs and Students Learning Approaches: the Role of Classroom Structure Perception. International Journal of Educational Psychology, 4(3), 305-328, doi: 10.17583/ijep.2015.1137

Ministry of Higher Education. (2013). Statistics of Higher Education of Malaysia. Retrieved from Malaysia: www.mohe.gov/web_statistik/index.htm

Moradi, B., \& Subich, L. (2004). Examining the moderating role of selfesteem in the link between experiences of perceived sexist events and psychological distress. Journal of Counseling Psychology, 51, 50-56, doi: 10.1037/0022-0167.51.1.50

Nagy, H., \& Smith, P. (2016). The Era of the Global Intern? Business Undergraduates' Perceptions of International Internships at a Foreign University in Vietnam Smart Technologies for Smart Nations (pp. 91-108): Springer, doi: 10.1007/978-981-287-585-3_7

Potgieter, I. (2012). The relationship between the self-esteem and employability attributes of postgraduate business management students. SA Journal of Human Resource Management, 10(2), 15 pages.

Purdie, F., Ward, L. J., McAdie, T. M., King, N., \& Drysdale, M. (2013). Are work-integrated learning (WIL) students better equipped psychologically for work post-graduation than their non-workintegrated learning peers? Some initial findings from a UK university. Asia Pacific Journal of Co-operative Education, 14(2), $117-125$.

Raelin, J. A. (2008). Work-based learning: Bridging knowledge and action in the workplace: John Wiley \& Sons.

Raelin, J. A., Bailey, M. B., Hamann, J., Pendleton, L. K., Raelin, J., Reisberg, R., \& Whitman, D. (2011). The effect of cooperative education on change in self-efficacy among undergraduate students: Introducing work self-efficacy. Journal of Cooperative Education and Internships, 45(2), 17-35. 
Rappaport, J. (1984). Studies in empowerment: Introduction to the issue. Prevention in Human Services, 3, 1-7.

Ringle, C. M., Wende, S., \& Will, A. (2005). SmartPLS 2.0 (beta): Hamburg.

Rosenberg, M. (1965). Society and the adolescent self-image. Princeton, NJ: Princeton University Press.

Safari, K., Haghighi, A. S., Rastegar, A., \& Jamshidi, A. (2011). The relationship between psychological empowerment and organizational learning. Procedia-Social and Behavioral Sciences, 30, 1147-1152, doi: 10.1016/j.sbspro.2011.10.224

Shrauger, J. S., \& Schohn, M. (1995). Self-confidence in college students: Conceptualization, measurement, and behavioral implications. Assessment, 2(3), 255-278.

Smith, C., Ferns, S., \& Russell, L. (2016). Designing work-integrated learning placements that improve student employability: Six facets of the curriculum that matter. Asia-Pacific Journal of Cooperative Education, 17(2), 197-211.

Smith, C., \& Worsfold, K. (2014). WIL curriculum design and student learning: a structural model of their effects on student satisfaction. Studies in Higher Education, 39(6), 1070-1084, doi: 10.1080/03075079.2013.777407

Spowart, J. (2011). Hospitality Students' Competencies: Are They Work Ready? Journal of Human Resources in Hospitality \& Tourism, 10(2), 169-181, doi: 10.1080/15332845.2011.536940

Spreitzer, G. M. (1995). Psychological empowerment in the workplace: Dimensions, measurement, and validation. Academy of Management Journal, 38(5), 1442-1465, doi: 10.5465/256865

Stone, M. (1974). Cross-validatory choice and assessment of statistical predictions. Journal of the royal statistical society. Series B (Methodological), 111-147, doi: $\quad 10.1111 / \mathrm{j} .2517-$ 6161.1974.tb00994.x

Tracy, J. L., Cheng, J. T., Robins, R. W., \& Trzesniewski, K. H. (2009). Authentic and hubristic pride: The affective core of self-esteem and narcissism. Self and identity, 8(2-3), 196-213, doi: $10.1080 / 15298860802505053$ 
Velde, M., \& Berg, P. (2003). Managing functional flexibility in a passenger transport firm. Human Resource Management Journal, 13(4), 45-55, doi: 10.1111/j.1748-8583.2003.tb00104.x

Wang, J. L., Zhang, D. J., \& Jackson, L. A. (2013). Influence of self-esteem, locus of control, and organizational climate on psychological empowerment in a sample of Chinese teachers. Journal of Applied Social Psychology, 43(7), 1428-1435, doi: 10.1111/jasp.12099

Wang, Y., \& Wang, L. (2016). Self-construal and creativity: The moderator effect of self-esteem. Personality and Individual Differences, 99, 184-189, doi: 10.1016/j.paid.2016.04.086

Zajacova, A., Lynch, S. M., \& Espenshade, T. J. (2005). Self-efficacy, stress, and academic success in college. Research in higher education, 46(6), 677-706, doi: 10.1007/s11162-004-4139-z

Zegwaard, K. E., \& McCurdy, S. (2014). The influence of work-integrated learning on motivation to undertake graduate studies. Asia-Pacific Journal of Cooperative Education, 15(1), 13-28.

Amar Hisham Jaaffar is a Senior Lecturer of Organizational Behaviour in the Department of Business and Management, Universiti Tenaga Nasional.

Hazril Izwar Ibrahim is an Associate Professor of Organizational Behaviour in the School of Management at Universiti Sains Malaysia.

Jegatheesan Rajadurai is an Associate Professor of Marketing in the Department of Business and Management, Universiti Tenaga Nasional.

M. Sadiq Sohail is a Professor of Marketing in the Department of Management and Marketing, King Fahd University of Petroleum and Minerals.

Contact Address: Corresponding author's email: Ahisham@uniten.edu.my 